DEVELOPING KAMISHIBAI MEDIA FOR WRITING NARRATIVE TEXT AT JUNIOR HIGH SCHOOL

AN ARTICLE

Submitted to in Partial Fulfillment of Requirements for The Degree of Sarjana Pendidikan

By:

FITRI ANISAH SITORUS

Registration Number: 2132121014

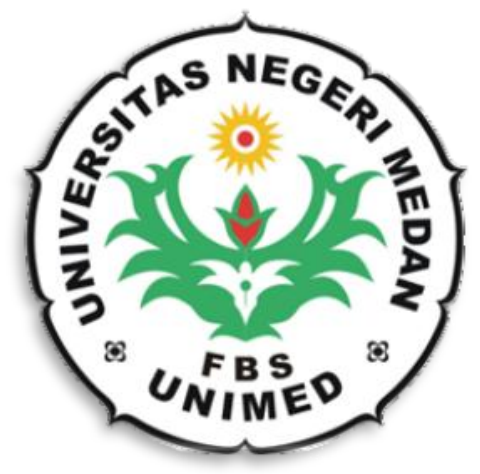

ENGLISH AND LITERATURE DEPARTMENT

FACULTY OF LANGUAGES AND ARTS

MEDAN STATE UNIVERSITY

2018 
ARTIKEL

\title{
DEVELOPING KAMISHIBAI MEDIA FOR WRITING NARRATIVE TEXT AT JUNIOR HIGH SCHOOL
}

\author{
Disusun dan Diajukan oleh:
}

Fitri Anisah Sitorus

Registration Number: 2132121014

\section{Telah diverifikasi dan dinyatakan memenuhi syarat untuk diunggah pada jurnal online}

Medan, Januari 2018

\section{Menyetujui}

Dosen Pembimbing I

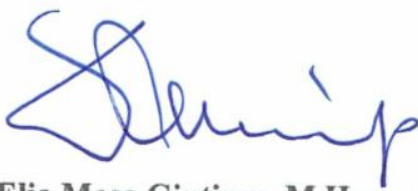

Drs. Elia Masa Gintings, M.Hum. NIP. 195807071985031007
Dosen Pembimbing II

Rafika Dewi Nst, S.Pd., M.Hum.

NIP. 197801082005012003

Ka. Program Studi

Pendidikan Bahasalnggris

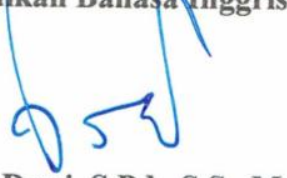

Nora Ronita Dewi, S.Pd., S.S., M.Hum.

NIP. 198005222008122003 


\title{
DEVELOPING KAMISHIBAI MEDIA FOR WRITING NARRATIVE TEXT AT JUNIOR HIGH SCHOOL
}

\author{
* Fitri Anisah Sitorus \\ ** Elia Masa Gintings \\ ** Rafika Dewi Nasution
}

\begin{abstract}
The objective of this study was to develop Kamishibai media based on students' needs. Research and Development was used as the research method. Research procedure was modified into four steps: Evaluation and Need Analysis, Media Design, Validation and Revision, and Final Production. The subject of this study was class VIII students of Mts. Muallimin Univa Medan, consisting of 44 students. The data were collected by giving Questionnaire to the students' and interviewing to the teacher. The products had validated by experts validation (Material and Media). The average scores is $81 \%$ from English Lecture and $84 \%$ from English Teacher and the total average scores is $83 \%$. It means that developing Kamishibai media categories is relevant or appropriate for VIII Grade student of Mts. Muallimin Univa Medan.
\end{abstract}

Key words: Research and Development ( $R \& D)$, Kamishibai Media, Narrative Text, Junior High School

\footnotetext{
*Graduate

** Lecturer
} 


\section{INTRODUCTION}

\section{Background of the Study}

English is global language which is used by people around the world. It is use in all activities as a formal language. Taking Part in activities, Indonesia people must have a good competence in using English, because it can achieve many opportunities to our country. English is first foreign language taught at every school in Indonesia. So, it is important to teach in Junior High School as a compulsory subject. There are four skills which need to learn. Namely are Listening, Speaking, Reading and Writing.

In mastering English, most students in Indonesia consider English is difficult subject that make frustrated and they get problems in writing and speaking skill. Many of them failed to graduate in Junior High School to Senior High School only because of students' has lack on vocabulary, the students' not interested in learning, the teachers' seldom use real media, and the students' difficult to express ideas, sometimes students have ideas but they are still confused how to develop it as the correct one so they can't make a good paragraph (Prasetyo, 2016).

Writing is one of important and difficult skill for foreign language learners in learning English because writing depends on grammar, vocabulary, spelling, and punctuation as well as rule for forming words and making sentences. Writing in Junior High School consists of descriptive, narrative, recount, report, and 
procedure text. The students able to understand and produce a narrative text based on the social function and generic structure of the text.

Writing is a natural step of steps that writer take to create a finished piece of work. By writing we are free to express our ideas, to sharpen main idea through writing form and writing is a process of organizing ideas and creativity thought text (Brown, 2001). Writing is an activity that can useful be prefared for by work in other skill of listening, speaking, and reading. This preparation can make it possible for words that have been used recepitively to come into productive use (Nation, 2009).

In Indonesia almost every institution of education from University, Senior High School, Junior High School, and Elementary School teach English to their students because English subject include as a test in the National Examination. So, it should apply properly and to make it apply properly, the teachers' needs media that support the English learning run well, fun, and make it students' able to understand on learning English. In teaching English, teachers should select the appropriate media that can use in the class. The media must support students to increase their enthusiasm and creativity to learn English. So, the students will enjoy the learning process of activity provide with media. Therefore, using media will give innovation, creativity, and enthusiasm on education. Media can create an atmosphere of interactive learning in a classroom. Media will give stimulus for students to reach the learning process. It means, students will get stimulus to think, feel, and to have desire to study so they will give attention to study when the learning process is provided with media (Manurung, 2012). 
Media based visual is the appropriate media to support the English learning process. Visual media can facilitate understanding and strengthen memory because the form of visual media is image representative such as drawing, painting or photograph that show how apparently an object (Arsyad, 2013).

McGowan (2011) stated that Kamishibai can build students confident in performing and allows them to discover what works best of them in creating stories. Nozaka (2013) stated that Kamishibai is a good for cross-cultural understanding of children. Dym (2010) doing study about the using Kamishibai at schools in Japan and he said that kamishibai similar to wayang show in indonesia, the purpose is sending moral lesson to society. Kamishibai used as a media to help students to think out loud and gain confidence in writing (Baird, 2010). PaatelaNieminen (2008) stated that kamishibai it can use as visual culture on education and have a good relation in global.

Various media of teaching English have been applied by teacher such as text book, print-out of text and dictionary. But the media is not enough to stimulate students in writing ability. Teachers asked the students to open their mind and use their imaginary to write story based on their surroundings. It makes learning process is conducive but it is not interesting to students.

It was supported by the preliminary data done by the researcher on May 2017 at Mts Muallimin Univa Medan. Teacher doesn't use varieties media to teach writing skill in the classroom. He always joint his students by open minded 
and asked his students to imaginary before they wrote story. Besides that, the teacher's used a text book, print-out of text and dictionary as media that can be involved by the students.

The resume of the preliminary data above showed that the teachers' doesn't use varieties media to teach writing skill. The teacher usually used the video and an English textbook by the government. While in fact, the teacher need a new media that can involve by the students when teaching learning process happened.

From the condition the researcher saw that the teachers need another teaching media that can help them to teach their student which is designed appropriate for students need. (Helmi, 2017) developed kamishibai media used for storytelling narrative in MTs Aljam'iyatul Wasliyah Tembung and found that kamishibai media can motivate students in learning process especially in speaking skill. (Rachman, at al, 2017) developed kamishibai as a media to learn environment education for children and to build capacity for teacher and found that it can improve the competences of student in creative thinking skill in solving environmental problem around them. (Provesa, 2014) conducted an experimental study was to determine the effectiveness of using short comics in teaching of narrative writing at one Islamic Junior High and the result is it can motivate students and help them increase the achievement in writing. From the three research results of kamishibai used as a learning medium was gave motivated, creative in thinking, and help them to increase the achievement, this study focused on 1 to 9 levels and there was three genres and two skills. 
(Poedjiastuti, 2010) developed magazines for writing class in university and the result did not show a great variability of the student's responses but students gave positive responses on the project of magazines. (Kennedy, 2014) also developed cartoons for long term condition self-management information and the result was the process depict patient experiences, common situations, and daily management dilemmas. This research focused on writing skill but different levels and the research result was good and made a new experience to students learning used appropriate media.

Therefore, this study was to develop a kamishibai media that make students more enthusiasm and interested in writing narrative text. 


\section{RESEARCH METHODOLOGY}

This study was conducted based on educational Research and Development design or (R\&D) model by Borg and Gall (2003) which is consists of set of steps to develop a new educational product. According to Sugiyono (2014) the methods of researcher and development are the researcher methods used to produce a specific product and test the effectiveness of the product. This study was done into four phases covering 1). evaluation and need analysis, 2). media design, 3).validation and revision and 4). Final Production. The product result in this study is kamishibai media for writing narrative text at VIII Junior High School.

The research place was at Mts. Muallimin Univa Medan which consists of 44 students. The source of data was syllabus, lesson plan, teachers' interview and students' questionnaires as qualitative data. The questionnaires and interview were the instruments of research that analyze descriptively.

In collecting the data the writer used questionnaires and interview. The first the writer observed the syllabus and material, analyze the basic competence, students' worksheet, and the book. The second the writer did interview section to the English teacher who teaches in eight grade of Mts. Muallimin Univa Medan. It had function to get information about students, problem which was faced in learning English especially writing, and also about the materials. The third, the writer gave the questionnaires to the students in order to get information about students' need in learning English. In this 
section the writer shared the questionnaire. So, the writer can get information toward students' need, problem in learning English and their interest in writing.

The conceptual frameworks of stages developing media kamishibai for writing narrative.

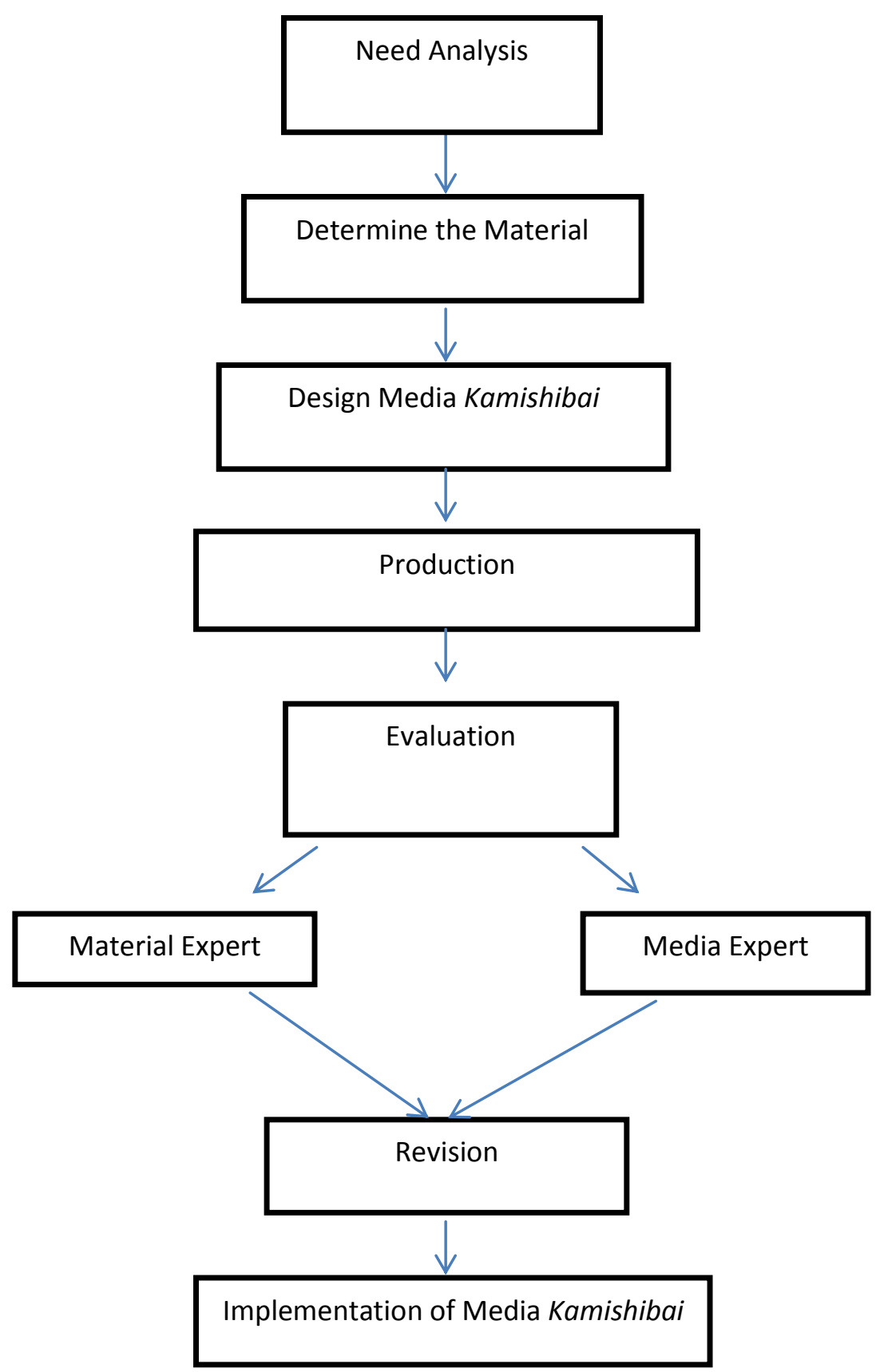




\section{MATERIALS DEVELOPMENT}

The aim of this study was to develop kamishibai Media as learning media based on students need at Mts Muallimin Univa Medan. The researcher administered the questionnaire to the students and the interview to the English teacher. There were 12 questions that were answered by the students. The questionnaire itself was developed based on the theory proposed by Hutchinson and waters (1986). They stated that in order to do the needs analysis, there are three categories of questions which should be covered, namely: necessities, lacks, and wants.

Target needs are what the learners need to do in the target situations it was consisted the term of necessities, lacks, and wants. Most of students said that writing skill is difficult to learn, some students said they often felt so bored in learning English writing. They also gave the opinion narrative text is the text which is difficult to learn because using past tense, besides that, they also less of idea in writing the text. And in teaching learning process the students prefer the teacher should be teaching by certain media. Most of them said that the media that teacher used is less of good because not appropriate with the topic. So, teacher must match the material and the media used.

After the needs analysis had been conducted, the next step was designing kamishibai media. For the first step, the researcher determine the material from syllabus, then began to develop kamishibai media and the material. After develop kamishibai media, the findings of this study could be seen below: 
Media was developed from the original version so that it can be adapted to the MTs Al-Jami'yatulTembung. The development is the physical aspect in which the media is made as efficient as possible in order to be taken anywhere.

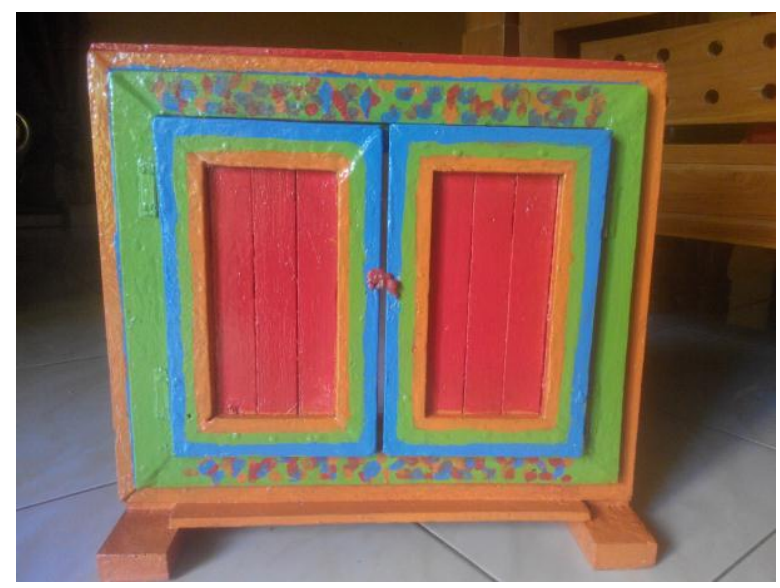

The picture of Butai

In terms of story, The content of the story is modified in accordance with the school-based religion of Islam. In addition to Islamic stories, stories that are used are also stories coming from another country in order to meet the need for students to know the stories of the cultures of other countries. The stories are Hud-Hud and Prophet Solomon,

The next step was expert judgment process. The materials were evaluated by two experts. The criteria for expert judgment were based on the BSNP standard (Contents, language use, methodology and layout). In the process of experts judgments, there are some mistake should be replace, such as grammatical, spelling, and the vocabularies. Therefore, to get the quality of the product, the researcher gave it to the validator to be validated. The validators came from and English Lecturer from State University of Medan as the first validator and an 
English Teacher from Mts Muallimin Univa Medan as the second validator. As the result from the first validator evaluation got $81 \%$ (Relevant). Beside that from the second validator evaluation also got $84 \%$ (Relevant). Thus, the final draft or the developed Kamishibai media for writing Narrative text were valid and appropriate to be used as learning materials for eight grade students of Mts.Muallimin Univa Medan. 


\title{
CONCLUSION AND SUGGESTIONS
}

\author{
The Conclusion
}

Developing Kamishibai media for writing narrative text at Junior High School follows Research and Development (R \& D) model by Gall, Borg and Gall's (2003) which consist of a set of step to develop new educational product. Then, the step of Kamishibai media are modified in to four steps, they are: 1) evaluation and analysis 2) media design 3) validation and revision 4) final production. The product of developing Kamishibai media for teaching writing for eight-grade students of Mts. Mu'allimin Univa Medan has validated by expert validation (material and media). For the total assessment by material expert is 81 (Good), and the total assessment by the media expert is 84 (Good). With the result that kamishibai media is good and eligible to use for teaching writing for eightgrade students of Mts. Mu'allimin Univa Medan.

\section{The Suggestions}

The use of Kamishibai media would be more effective if teachers are using this media bring the story narrative with more creative and communicative as the essence of kamishibai media utilization is as an intermediary of communication between the storyteller and the listener. With higher creativity and more intense communication, the media not only serves to narrative story to students, but also to motivate and provide higher confidence of the students to use English more frequently in daily conversation. Other researcher. This media consist of one story as the material; the story from Al-Quran is the story of Solomon's Messenger 
Bird. For other research can be adding another story as the material for Kamishibai media. 


\section{REFERENCES}

Alkaaf, F., and Al-Bulushi, A. (2017). Tell and Write, the Effect of Storytelling Strategy for Developing Story Writing Skills among Grade Seven Learners. Open Journal of Modern Linguistics, 7, 119-141.

Annadale NSW. (1990). A Genre-Based Approach to Teaching Writing in Years 3-6 Book 4: The Theory and Practice of Genre-Based Writing. Sydney:Department of School Education.

Anderson, Mark and Kathy Anderson. (1997). Text Types in English 2. South Yarra: Macmillan Education Australia.

Angkowo, R and Kosasih,A. (2007).Optimalisasi media, Jakarta: Grasindo.

Apple, M and Kikuchi, K.(2007). Practical PowerPoint group projects for the EFL classroom. The JALT CALL Journal, 3,110-122.

Arsyad, A. (2013).Media Pembelajaran.Jakarta:PT Raja grafindo persada.

Baird, Pauline. (2010). Making College Writing Fun for ESL and EFL Learner Using Kamishibai.The Internet TESL Journal,16,11.

Brown, Douglas. (2004). Language Assessment: Principles and Classroom Practices. New York: Longman.com

Borg \& Gall.(2003). Research and Development in Education. Cambridge: Cambridge University Press.

Casas, D. L. (2006). Kamishibai story theater: The art of picture telling. London: Teacher ideas press.

Dirgayasa, I W. (2014) The Development of English Writing Learning Material Through a Genre Based Approach for English Department at University, International Seminar on English Language and Teaching (ISELT),.

Dym, J. A. (2007). Kamishibai what is it?some preliminary findings. http:// www.kamishibai.com. April $8^{\text {th }} 2017$.

Ellis, G and Brawster, J.Farmer, M. et al. (1985) Composition and Grammar: Steps in the Writing Process. Chicago: Laidlaw Brothers.

Gerot, Linda and Peter Wignell. (1995). Making Sense of Functional Grammar.

Sydney: Gerd Stabler. 